\title{
PERANCANGAN DAN IMPLEMENTASI PENGONTROL SUHU RUANGAN BERBASIS MIKROKONTROLLER ARDUINO UNO
}

\author{
Dias Prihatmoko \\ Fakultas Sains dan Teknologi \\ Universitas Islam Nahdlatul Ulama Jepara \\ diasprihatmoko@unisnu.ac.id
}

\begin{abstract}
ABSTRAK
Indonesia merupakan negara berkembang yang penduduknya banyak bergerak di bidang pertanian dan industri kecil. Untuk itu pengembangan tehnologi di bidang industri kecil perlu ditingkatkan untuk menghasilkan terobosan terobosan baru. Sebagai contoh perkembangan teknologi piranti piranti digital seperti mikrokontroler. Pemanfaatan mikrokontroler akan banyak membawa dampak pada kemudahan dan efektivitas kerja. Sebagai contoh rancang bangun sistem kontrol suhu ruang akan sangat bermanfaat pada proses kegiatan bekerja para pegawai industri dan perkantoran menengah yang efisien. Studi ini mengajukan perancangan simulasi sistem kontrol suhu dan beserta implementasinya berupa prototype sistem kontrol suhu ruangan menggunakan mikrokontroller arduino. Sistem kontrol suhu ini dilengkapi dengan kemampuan untuk mengontrol suhu ruangan yang dapat ditampilkan di LCD. Metode perancangan sistem dimulai dari kajian arsitektur sistem, perencanaan sistem kontrol suhu, dan pembuatan prototype sistem kontrol suhu. Penelitian ini menghasilkan prototype sistem kontrol suhu yang dilengkapi dengan fitur penampil suhu dengan LCD, sehingga suhu ruangan akan tertampil di LCD, apabila suhu tertampil diluar batas maksimum maka akan menghidupkan pendingin ruangan dan pendingin akan mati jika suhu berada dibawah batas minimum. Sistem ini bekerja dengan menggunakan beberapa perangkat diantaranya: Arduino, Sensor Suhu, Pendingin, dan Penampil Suhu (LCD).
\end{abstract}

Kata kunci: arduino, sistem kontrol suhu, simulasi kontrol suhu proteus.

\begin{abstract}
Indonesia is a developing country with population is much engaged in agriculture and small industry. The industri need technological touch, such as microcontroller digital device. The utilization of the microcontroller will be useful for automatic monitoring, for example design room temperature control system will be useful to energy efficient. This study propose to design of temperature control system simulation and implementation along with a prototype of the room temperature control system using microcontroller arduino. Temperature control system is able to control the room temperature and be displayed on the LCD. Method of study starts from the study of the architecture of the system, temperature control system design, and manufacture of temperature control system prototype. This research resulted in a prototype temperature control system equipped with LCD viewer with the temperature. The result are the room temperature will be displayed on LCD, when the temperature is displayed outside the maximum limit then it will turn on air conditioners and cooling will die if the temperature is below the minimum limit. The system works by using multiple devices including: Arduino, Temperature Sensor, Cooling, and Viewer Temperature (LCD).
\end{abstract}

Keywords: arduino,temperature control, temperature sensor.

\section{PENDAHULUAN}

Kebutuhan energi listrik nasional terus meningkat. Peningkatan ini disebabkan pemakaian energi listrik yang besar pada gedung, industri dan pabrik. Di sisi lain, pemakaian energi listrik masyarakat juga sangat boros. Hal ini disebabkan karena kurang memperhatikan besar kecilnya daya (watt) peralatan listrik yang digunakan. Kondisi ini akan berimbas pada sektor gedung perkantoran yang kebanyakan menggunakan energi listrik dari PLN. Permasalahan ini harus ditanggapi secara saksama para pengelola gedung untuk menekan pemakaian energinya. Salah satu cara yang paling mudah adalah dengan memanfaatkan energi secara maksimal melalui program hemat energi.

Penghematan energi adalah pemanfaatan energi secara efisien dan rasional tanpa mengurangi penggunaaan energi yang memang benar-benar diperlukan. Penghematan energi pada gedung dan industri bila dilaksanakan secara sistematis akan berpotensi mengurangi konsumsi energi yang besar. Namun pada 
prakteknya program penghematan energi tersebut masih menemui beberapa kendala. Salah satu masalah yang dihadapi dalam melakukan penghematan energi adalah sistem pengontrolan peralatan listrik pada gedung saat ini masih tergolong konvensional yaitu dengan menggunakan saklar. Sebagai contoh yaitu pendingin suhu ruangan di beberapa gedung masih menggunakan sistem manual yaitu dihidupkan menggunakan remote.

Gedung-gedung yang memiliki jumlah ruangan yang banyak, sering kali pendingin suhu ruangan tetap menyala padahal sudah di luar jam kerja, bahkan kadang-kadang sampai pagi. Hal ini disebabkan oleh kelalaian pengguna ruangan dan juga petugas yang harus mengecek peralatan pendingin suhu ruangan pada setiap ruangan. Kondisi seperti ini akan menyebabkan pemborosan energi listrik apabila terjadi berulang-ulang. Oleh karena itu perlu adanya sistem kontrol suhu ruangan pada gedung yang lebih praktis dan efisien. Sistem kontrol tersebut di setting secara otomatis dengan menggunakan sensor suhu yang akan membaca suhu ruangan dan dipadukan dengan teknologi microcontroller.

Beberapa usaha dan penelitian terkait dengan pengontrolan suhu sudah dilakukan, beberapa diantaranya yaitu : Penelitian yang dilakukan oleh asrofi dan bambang eka purnama yang berjudul Rancang Bangun Alat Kontrol Otomatis Pendingin Komputer Berbasis Mikrokontroller ATMEGA8L dengan memanfaatkan rangkaian mikrokontroller ATMega8L yang mengganti saklar manual pendingin tambahan (kipas) [1]. Manfaatnya alat kontrol suhu komputer tersebut secara otomatis menjalankan pendingin komputer untuk pengendalian suhu menjaga kestabilan kinerja hardware pada komputer yang berbasis Mikrokontroller ATMega8L. Komponen-komponen utama, pendukung, dan perangkat lunaknya disesuaikan. Antara lain rangkaian power suplly, rangkaian sistem minimum, rangkaian sensor suhu IC LM35 dan rangkaian alat lainnya. Serta perangkat lunak yang digunakan Code Visio Evaluation dan AVR studio. Hasil dari penelitian ini berupa prototype sistem pengontrol suhu otomatis yang ditempatkan didalam casing komputer.

Penelitian yang dilakukan oleh Masruchin yang berjudul Sistem Kendali Suhu Ruang Berbasis Mikrokontroller AT89S51 [2]. Penelitian ini dilakukan dengan membuat prototype sistem kendali suhu ruangan menggunakan mikrokontroller AT89S51. Mikrokontroller tersebut merupakan mikrokontroller dengan fasilitas yang bisa dikatakan terbatas. Sistem kerja dari perangkat tersebut adalah Pada saat saklar dinyalakan, komponen-komponen pada implementasi sistem penghangat pada kendali suhu ruangan dengan sensor LM35 berbasis mikrokontroler AT89S51 akan aktif secara hardware maupun secara software.. Data hasil pengindraan yang berupa tegangan ( data analog ), dimana untuk setiap kenaikan suhu 10C manghasilkan kenaikan tegangan sebesar 10 mVolt.

Penelitian yang dilakukan oleh Luthfi Hendra Lukmana yang berjudul Rancang Bangun Pengendali Lampu Ruangan Menggunakan Remote Control dan Real Time Clock Berbasis ATMega8535 [3]. Penelitian ini menggunakan remote control untuk mengendalikan lampu ruangan. Penggunaan remote control ini tentu menjadi salah satu penerapan prinsip kerja yang praktis dan fleksibel untuk lebih memudahkan dalam mengembalikan lampu ruangan. Data yang dikirimkan oleh remote akan diterima oleh sensor penerima infra merah untuk diteruskan ke mikropengendali. Pada mikropengendali data akan diproses dan dieksekusi untuk mengendalikan sistem kerja keseluruhan rangkaian. Pemrograman dengan menggunakan bahasa assembler umumnya berukuran kecil sehingga hemat dalam penggunaan memori dan dapat dieksekusi dengan cepat. Real time clock akan menyimpan data untuk referensi pewaktuan pada kendali lampu ruangan sehingga otomatisasi dan pemadaman lampu dapat berfungsi.

Beberapa penelitian tersebut diantaranya masih menggunakan mikrokontroller yang sudah lama dan dipasaran sudah jarang yang jual, oleh karena itu digunakan arduino uno dengan teknologi microcontroller yang lebih baru dan banyak tersedia dipasaran. Penelitian yang dilakukan berdasarkan latar belakang diatas adalah dengan membuat prototype berupa sistem pengontrol suhu ruangan berbasis microcotroller arduino uno. Sistem akan membaca suhu ruangan, apabila suhu yang dibaca sudah melebihi batas atas suhu yang direkomendasikan maka pendingin ruangan akan menyala. Alasan digunakan microcontroller arduino karena arduino mempunyai beberapa kelebihan diantaranya adalah low power dan banyak tersedia di pasaran jadi mudah untuk mencari alat dan bahannya.

\section{METODOLOGI PENELITIAN}

Untuk mewujudkan suatu sistem kontrol suhu menggunakan sensor suhu, maka pada bagian ini akan dijelaskan tentang langkah-langkah dan alat-alat yang digunakan dalam penelitian.

\subsection{Langkah-langkah Penelitian}

Langkah-langkah yang dilakukan dalam penelitian ini dipaparkan pada diagram alir di gambar 1 . 


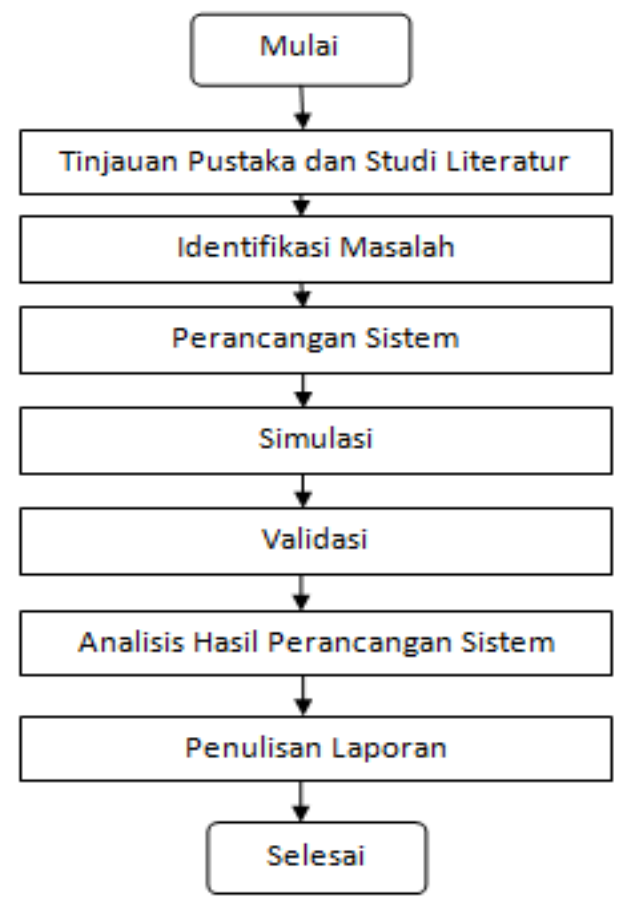

\section{Gambar 1. Diagram Alir Langkah-Langkah Penelitian}

Tinjauan pustaka dan studi literature dilakukan untuk mencari referensi yang sesuai dan berhubungan dengan topik penelitian yang dilakukan. Adapun referensi-referensi yang dirujuk dalam penelitian ini berkaitan dengan kajian sistem kontrol pada microcontroller beserta metode-metodenya.

Berdasarkan referensi-referensi tersebut dilakukan proses pengidentifikasian masalah yang akan diselesaikan dan diteliti di penelitian ini. Pada tahap ini juga dilakukan kajian mengenai perbedaan yang dilakukan dengan penelitian-penelitian yang telah dilakukan sebelumnya, hasil identifikasi menjadi rumusan masalah yang akan diselesaikan dalam penelitian.

Perancangan sistem dilakukan berdasarkan kajian dan uji coba yang dilakukan terhadap semua kajian, teori dan metode yang berhubungan dengan topik penelitian. Kajian-kajian tersebut terkait dengan : (1) arsitektur sistem, (2) perancangan dengan simulasi menggunakan software proteus (3) rancangan sistem kontrol suhu, dan (4) peralatan yang digunakan dalam perancangan. Setelah semua pilihan tersebut ditentukan, maka dilakukan perancangan sistem berdasarkan permasalahan yang muncul dibagian identifikasi masalah.

Langkah selanjutnya adalah Simulasi dilakukan untuk uji coba perancangan sistem secara software, yaitu menggunakan software proteus profesional 8. Serta Validasi dilakukan untuk memastikan bahwa perancangan sistem bisa diterapkan secara real yaitu diaplikasikan di rangkaian arduino dan bisa berjalan dengan baik.

Perancangan sistem menghasilkan sebuah sistem yang belum stabil dan memerlukan pengujian untuk mengoptimalkan kinerja secara keseluruhan. Pengujian dilakukan terhadap bagian-bagian penting dari sistem. Bagian-bagian penting tersebut antara lain : (1) Sistem kontrol suhu ruangan (2) Perbandingan antara sistem dengan alat pengukur ruangan secara manual. Pengujian dilakukan hingga dicapai hasil terbaik berdasarkan pengujian dan analisis.

Sedangkan langkah selanjutnya adalah pengujian dan analisis sistem menghasilkan sistem yang lebih baik secara keseluruhan. Hasil analisis dan pengujian dilanjutkan dengan penulisan laporan penelitian.

\subsection{Alat dan Bahan}

Sistem yang dikembangkan membutuhkan beberapa perangkat keras, Perangkat keras ini berperan utama dalam perancangan sistem, Adapun perangkat keras yang digunakan dalam perancangan sistem ini adalah sebagai berikut :

1) Arduino

2) Sensor Suhu LM35DZ

3) FAN

4) $\mathrm{LCD}$ 
Sedangkan perangkat lunak yang digunakan dalam merancang dan membangun sistem terdiri dari :

1) Notepad++ merupakan tools yang digunakan untuk membuat script yang digunakan untuk memprogram mikrokontroller.

2) Proteus 8 Profesional merupakan aplikasi yang digunakan untuk simulasi perancangan sistem pengontrol suhu.

3) Sketch Arduino merupakan aplikasi untuk compile dan upload program kedalam mikrokontroller Arduino.

\subsection{Alur Kerja Sistem}

Perancangan sistem pengontrol suhu ruangan berbasis mikrokontroller arduino uno menggunakan sistem waterfall yaitu aliran satu arah. Yang diawali dengan tinjauan pustaka dan studi literatur untuk mengumpulkan data-data dan referensi yang akan digunakan dalam perancangan, selanjutnya adalah dilakukan pengidentifikasian masalah yang akan diselesaikan dan diteliti. Kemudian dilakukan perancangan sistem dengan melakukan berbagai kajian tentang arsitektur dan perancangan, kemudian dilakukan simulasi lalu validasi. Jika rangkaian sudah divalidasi dan diaplikasikan ke perangkat keras arduino uno, hal selanjutnya adalah melakukan pengujian untuk mendapatkan hasil serta dianalisa, dan akhirnya dibuat laporan penelitian.

\section{HASIL PENELITIAN DAN PEMBAHASAN}

\subsection{Simulasi}

Untuk simulasi dan validasi digunakan software proteus profesional 8 yang memang secara khusus software tersebut dibuat untuk simulasi rangkaian elektronik. Adapun hasil dari simulasi tersebut sebagaimana terdapat pada gambar 2. dibawah ini:

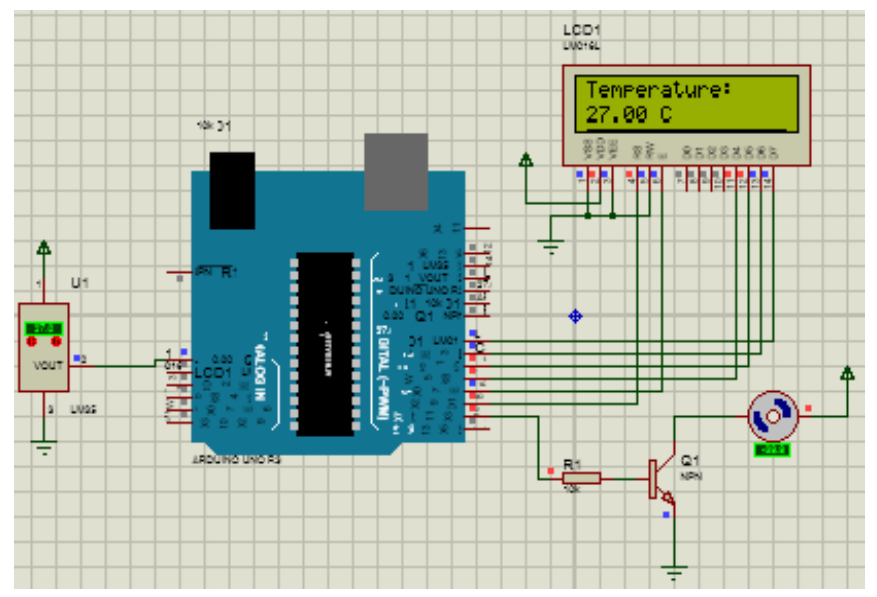

Gambar 2. Rangkaian Pengontrol Suhu Ruangan

Keluaran Sensor suhu LM35 dihubungkan ke pin Analog In (A0), sensor tersebut menjadi masukan dari mikrokontroller arduino. Sedangkan keluaran arduino berupa LCD 16 × 2 serta kipas, kipas dihubungkan ke pin digital 1 serta LCD dihubungkan ke pin digital 7, digital 6, digital 5, digital 4, digital 3 , digital 2. Sensor suhu membaca data analog secara real time berupa data suhu ruangan kemudian data tersebut masuk ke pin A0 dari mikrokontroller arduino, data tersebut oleh arduino diubah menjadi data digital untuk dapat diolah dan dihasilkan keluaran berupa kipas yang menyala untuk mendinginkan ruangan serta tampilan data suhu secara realtime menggunakan LCD. Untuk suhu kamar yang nyaman disetting antara rentang suhu 25 0C sampai dengan 28 0C. jika suhu ruang yang dibaca sensor melebihi 28 0C maka secara otomatis kipas akan menyala dan mendinginkan ruangan sampai suhu $250 \mathrm{C}$ dan jika suhu dibawah 25 0C maka kipas secara otomatis akan mati. Hal ini dilakukan untuk menghemat energi listrik yang dipakai diruangan tersebut.

Dari gambar 2, bahwa rangkaian tersebut telah sesuai dengan yang diharapkan, tertampil bahwa suhu 27 0C dan kipas masih menyala untuk mendinginkan ruangan sampai batas bawah suhu (25 0C). jika suhu dibawah 25 0C maka nantinya kipas secara otomatis akan mati. Rangkaian tersebut telah disimulasikan secara berulang-ulang dan hasilnya tetap stabil. Ini yang menjadi dasar untuk validasi sistem. Rangkaian tersebut telah disimpulkan bahwa rangkaian tersebut telah tervalidasi dan siap untuk dibuat rangkaian hardware elektroniknya. 


\subsection{Pengujian Kontrol Suhu}

Setelah rangkaian di simulasi dan di validasi maka langkah selanjutnya adalah perancangan rangkaian hardware serta pengujian sistem. Adapun hasil dari perancangan rangkaian hardware sistem kontrol suhu adalah sebagai berikut :

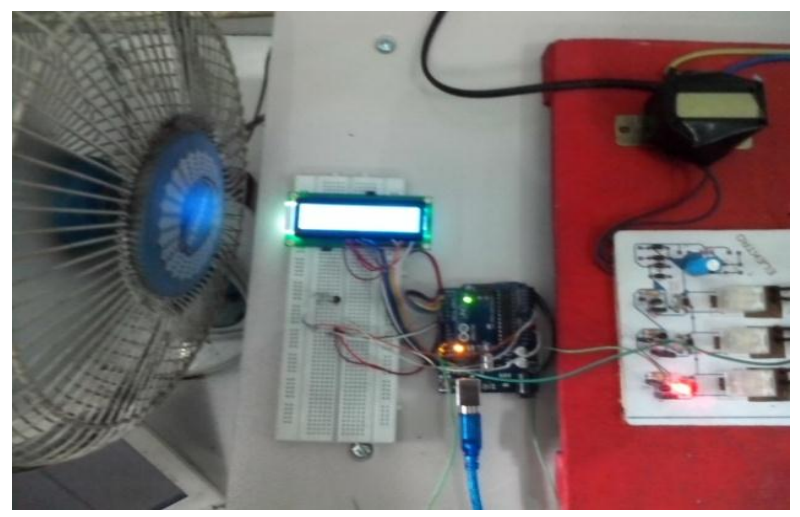

Gambar 3. Perancangan Rangkaian Hardware

Sistem kontrol suhu tersebut berfungsi untuk mendapatkan data suhu ruangan secara otomatis melalui sensor suhu LM35 kemudian ditampilkan di LCD serta untuk mengontrol suhu ruangan secara otomatis dengan cara menghidupkan dan mematikan kipas. Jika suhu ruangan melebihi ambang batas maka kipas akan dinyalakan sampai suhu mencapai ambang batas bawah, setelah suhu melampaui ambang batas bawah maka secara otomatis kipas akan dimatikan.

Pengujian dilakukan dengan membandingkan suhu termometer dengan suhu hasil pembacaan sensor suhu, dilakukan tiga kali pengujian sensor suhu pada suhu $25^{\circ} \mathrm{C}$ sampai dengan suhu $38^{\circ} \mathrm{C}$, hasil yang didapatkan kemudian dirata-rata. Hasil rata - rata sensor suhu kemudian dibandingkan dengan suhu termometer, dicari selisihnya. Selisih tersebut menunjukkan nilai error yang terjadi pada pengukuran.Nilai error tersebut dapat dihitung dengan menggunakan rumus :

Selisih Pengukuran Thermometer dengan Sensor X $100 \%$

Hasil pengukuran sensor suhu dapat dilihat pada tabel 1:

Tabel 1. Hasil Pengukuran Suhu Ruangan

\begin{tabular}{ccccccc}
\hline \multirow{2}{*}{$\begin{array}{c}\text { Suhu Termometer } \\
\text { (celcius) }\end{array}$} & \multicolumn{3}{c}{ suhu sensor(celcius) } & \multirow{2}{*}{$\begin{array}{c}\text { Rata-rata } \\
\text { Pengujian }\end{array}$} & Selisih & Error \\
\cline { 2 - 5 } & $\begin{array}{c}\text { Pengujian } \\
\boldsymbol{I}\end{array}$ & $\begin{array}{c}\text { Pengujian } \\
\text { II }\end{array}$ & $\begin{array}{c}\text { Pengujian } \\
\text { III }\end{array}$ & & & \\
\hline 25 & 25,7 & 25,7 & 25,5 & 25,63 & 0,63 & 2,53 \\
26 & 26,6 & 26,3 & 26,4 & 26,43 & 0,43 & 1,67 \\
27 & 27 & 27,2 & 27 & 27,07 & 0,07 & 0,25 \\
28 & 28,8 & 28 & 28,6 & 28,47 & 0,47 & 1,67 \\
29 & 29,6 & 29,5 & 29,8 & 29,63 & 0,63 & 2,18 \\
30 & 30,6 & 30,6 & 30,8 & 30,67 & 0,67 & 2,22 \\
31 & 31,8 & 31,8 & 31,65 & 31,75 & 0,75 & 2,42 \\
32 & 32,7 & 33 & 32,8 & 32,83 & 0,83 & 2,60 \\
33 & 34 & 34,2 & 33,8 & 34,00 & 1,00 & 3,03 \\
34 & 34,5 & 34,5 & 34,8 & 34,60 & 0,60 & 1,76 \\
35 & 35,6 & 35,8 & 36 & 35,80 & 0,80 & 2,29 \\
36 & 36,4 & 36,6 & 36,8 & 36,60 & 0,60 & 1,67 \\
37 & 37,8 & 37,8 & 37,8 & 37,80 & 0,80 & 2,16 \\
38 & 38,8 & 39 & 38,5 & 38,77 & 0,77 & 2,02 \\
& & Rata-Rata & & & $\mathbf{0 , 6 5}$ & $\mathbf{2 , 0 3}$ \\
\hline
\end{tabular}


Hasil pengujian yang ditampilkan pada tabel 1 diatas menunjukkan hasil pengukuran yang cukup baik. Pengukuran suhu yang didapatkan menunjukkan error rata-rata sebesar 2,03\%.. Perbedaan pengukuran ini terjadi karena proses pembulatan hasil pada sensor dan proses kalibrasi yang dilakukan masih kurang baik, sehingga perlu dilakukan kalibrasi yang lebih baik lagi. Hasil pengukuran kemudian dibuat grafik sebagai berikut :

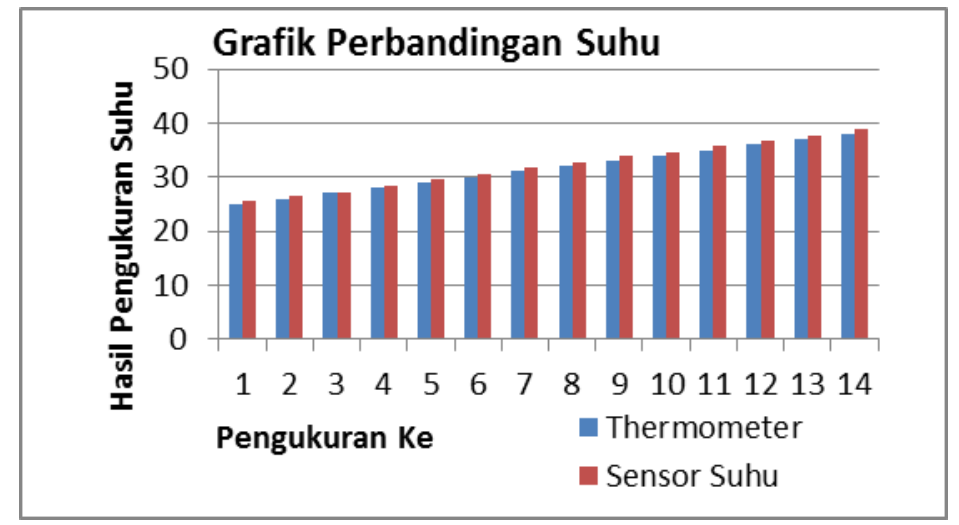

Gambar 4. Grafik Perbandingan Suhu

\section{KESIMPULAN} berikut :

Dari penelitian yang telah dilakukan, terdapat beberapa kesimpulan antara lain adalah sebagai

a. Penelitian menghasilkan Sistem Kontrol Suhu Ruangan yang dapat digunakan untuk mengontrol suhu ruangan secara otomatis menggunakan sensor suhu.

b. Sensor suhu LM35 merupakan sensor suhu yang baik dan layak digunakan untuk monitoring suhu ruangan.

c. Microcontroller Arduino Uno merupakan mikrokontroller open source dapat digunakan untuk mengolah data analog dari sensor.

d. Perancangan Dan Implementasi Pengontrol Suhu Ruangan Berbasis Mikrokontroller Arduino Uno dengan sensor suhu LM35 layak digunakan dan diaplikasikan sebagai sistem pengontrol suhu ruangan.

\section{DAFTAR PUSTAKA}

[1] Asrofi, dkk (2013). Rancang Bangun alat Kontrol Otomatis Pendingi Komputer Berbasis Mikrokontroller ATMega8L. Indonesian Journal on Networking and Security(IJNS) Volume 2 No 2. ISSN 2302-5700.

[2] Masruchin, dkk (2010). Sistem Kendali Suhu Ruang Berbasis Mikrokontroller AT89S51. Seminar Nasional VI SDM Teknologi Nuklir. ISSN 1978-0176. Yogyakarta.

[3] Lutfi HK, dkk (2013). Rancang Bangun Pengendali Lampu Ruangan Menggunakan Remote Control dan Real time Clock Berbasis ATMega8535. Program studi DIII sekolah Tinggi Teknologi Telematika Telkom Purwokerto.

[4] Alifia Nur Laili. (2013). Sistem On-Off AC pada Ruang Penyimpanan Barang-Barang Berharga Berbasis Mikrokontroller ATMega 16 Dengan Monitoring Via Web. PSD III Teknik Elektro, Fakultas Teknik, Universitas Diponegoro Semarang.

[5] Muhammad Syahwil. (2014). Panduan Mudah Simulasi dan Praktek Mikrokontroller arduino +CD. Andi. Yogyakarta.

[6] Denny Rachmawati, (2009). Rancang Bangun Sistem Kontrol Suhu Ruangan Berbasis Mikrokontroller AT89S51. Semarang

[7] Manik Alit Wastharini, dkk. (2010). Perancangan dan Implementasi Sistem Telemetri Suhu Ruangan Berbasis Mikrokontroller. Telkom University

[8] Dony Widiotomo, dkk. (2009). Pengontrol Temperatur Ruangan Berbasis Microcontroller AT89S51. KOMMIT, Jakarta

[9] Sulhan Setiawan. (2009). Mudah dan Menyenangkan Belajar Mikrokontreoller. ANDI. Yogyakarta.

[10] Iswanto, (2011). Belajar Mikrokontroller AT89s51 dengan bahasa C. Andi. Yogyakarta.

[11] Handayani Saptaji W (2013). Mudah Belajar Mikrokontroller dengan arduino. Widya Media.2007 